Revista de Metalurgia 51(2)

April-June 2015, e043

ISSN-L: 0034-8570

doi: http://dx.doi.org/10.3989/revmetalm.043

\title{
Thermal expansion behaviour of Long-Period Stacking Ordered (LPSO) phase
}

\author{
Gerardo Garcés $^{\mathrm{a}, \bowtie}$, Guillermo Requena ${ }^{\mathrm{b}, \mathrm{c}}$, Domonkos Tolnai ${ }^{\mathrm{d}}$, Pablo Pérez ${ }^{\mathrm{a}}$, \\ Paloma Adeva ${ }^{\mathrm{a}}$, José A. Jiménez ${ }^{\mathrm{a}}$, Andreas Stark ${ }^{\mathrm{d}}$, Norbert Schell ${ }^{\mathrm{e}}$ \\ ${ }^{a}$ Department of Physical Metallurgy, National Center for Metallurgical Research \\ (CENIM-CSIC), Avda. Gregorio del Amo 8, 28040 Madrid, Spain \\ ${ }^{\mathrm{b}}$ Institute of Materials Research, German Aerospace Centre, Linder Höhe, 51147 Köln, Germany \\ ${ }^{\circ}$ RWTH Aachen, 52056 Aachen, Germany \\ ${ }^{\mathrm{d}}$ Institute of Materials Research, Helmholtz-Zentrum Geesthacht, Max-Planck-Str. 1, 21502 Geesthacht, Germany \\ eStructural Research on New Materials, Helmholtz-Zentrum Geesthacht Outstation at DESY in Hamburg, Germany \\ Corresponding author: ggarces@cenim.csic.es
}

Submitted: 13 February 2015; Accepted: 17 April 2015; Available On-line: 22 May 2015

\begin{abstract}
The lineal thermal expansion coefficient of the 18R Long-Period Stacking Ordered (LPSO) structure was determined in the range between room temperature and $400{ }^{\circ} \mathrm{C}$ by dilatometry and synchrotron radiation diffraction. Results clearly show that the lineal thermal expansion coefficients for magnesium and the LPSO phase are similar and therefore no mismatch thermal stresses are generated at their interface in two-phase $\mathrm{Mg}-\mathrm{Y}-\mathrm{Zn}$ alloys containing this phase during thermomechanical processing.
\end{abstract}

KEYWORDS: Magnesium alloys; LPSO phase; Synchrotron radiation diffraction; Thermal expansion coefficient

Citation / Cómo citar este artículo: Garcés, G., Requena, G., Tolnai, D., Pérez, P., Adeva, P., Jiménez, J.A., Stark, A., Schell, N. (2015) "Thermal expansion behaviour of Long-Period Stacking Ordered (LPSO) phase". Rev. Metal. 51(2): e043. doi: http://dx.doi.org/10.3989/revmetalm.043.

RESUMEN: Coeficiente de dilatación térmica de la fase LPSO. El coeficiente lineal de expansión térmica de la fase LPSO con estructura cristalográfica $18 \mathrm{R}$ se determinó en el intervalo entre temperatura ambiente y $400{ }^{\circ} \mathrm{C}$ mediante dilatometría y difracción de radiación sincrotrón. Los resultados muestran claramente que el coeficiente lineal de dilatación térmica de las fases magnesio y LPSO son similares y, por tanto, no se generan tensiones térmicas en su intercara durante el procesado termomecánico de aleaciones bifásicas Mg-Y-Zn.

PALABRAS CLAVE: Aleaciones de magnesio; Coeficiente de dilatación térmica; Difracción de radiación sincrotrón; Fase LPSO

Copyright: (C) 2015 CSIC. This is an open-access article distributed under the terms of the Creative Commons Attribution-Non Commercial (by-nc) Spain 3.0 License.

\section{INTRODUCTION}

The aerospace and automotive industry is particularly interested in magnesium alloys for applications which require low density and high strength materials. Long Period Stacking Ordered Structures (LPSO) have received significant research interest in recent years as strengthening phase for $\mathrm{Mg}$ alloys. The reinforcing effect of LPSO structures in extruded $\mathrm{Mg}-\mathrm{Y}-\mathrm{Zn}$ alloys is due to a load transfer mechanism from the magnesium matrix to the stiffer LPSO phase. The Young's modulus of the LPSO phase is higher than that of the magnesium matrix (Oñorbe et al., 2011; Oñorbe et al., 2012; Tane et al., 2014) 
and, therefore, these alloys behave mechanically as a metal matrix composite. The reinforcing effect of the LPSO phase in the extruded alloys is effective up to temperatures below $250{ }^{\circ} \mathrm{C}$ (Oñorbe et al., 2012).

In metal matrix composites reinforced with ceramic phases, mismatch stresses are generated during heating-cooling cycles and thermomechanical process used in the industrial manufacturing, due to significant differences between the thermal expansion coefficients of the metal matrix and the ceramic reinforcement (normally around one order of magnitude) (Clyne and Whithers, 1993). These mismatch stresses are mainly localized in the vicinities of matrix/reinforcement interfaces and their sign and magnitude depend on the shape and size of the reinforcement, the CTE-mismatch between the components and eventual relaxation mechanisms acting in the matrix (Requena et al., 2012). Ultimately, a large build-up of internal stress may lead to unexpected and dramatic failure. Since the presence of residual stresses may lead to fracture at lower loads than might be expected and originate difficulties during cold working or forming.

In aluminium matrix composite is has been reported that residual stress induces a tensioncompression asymmetry where yield stress in compression is higher than in tension (Arsenault and Taya, 1987). This fact is caused by the development of compressive residual stress during the composite processing. In magnesium matrix composites, this effect is masked by the crystallographic texture. Although, compressive residual stresses have been also reported using synchrotron diffraction (Garcés et al., 2009; Garcés et al., 2011). In magnesium alloys containing a high volume fraction of LPSO elongated fibers, Hagihara et al. (2010a) showed that the Mg-7Y-2Zn (wt.\%) alloy exhibited a higher yield stress in compression than in tension. The existence of residuals stress between LPSO and magnesium matrix could explain this rare behaviour in magnesium alloys.

In the literature, however, almost no data are available on the thermal expansion coefficient of the LPSO phase in Mg-Zn-RE alloys. The alloy Mg-11Y-5Gd-2Zn-0.5Zr (wt.\%) alloy containing LPSO particles shows an average linear thermal expansion coefficient of $2.94 \times 10^{-5} \mathrm{~K}^{-1}$ (Chen et al., 2009). This paper evaluates the linear CTE of the LPSO phase using two different techniques, dilatometry and synchrotron diffraction from room temperature to $400{ }^{\circ} \mathrm{C}$, to confirm the existence of compressive residual stresses.

\section{MATERIALS Y METHODS}

The $\mathrm{Mg}_{97} \mathrm{Y}_{7} \mathrm{Zn}_{5}($ at.\%) alloy used for this study was prepared by melting high purity elements $\mathrm{Mg}, \mathrm{Y}$ and $\mathrm{Zn}$ and $\mathrm{Mg}-22 \% \mathrm{Y}(\mathrm{wt} . \%)$ master alloys in a graphite crucible coated with boron nitride under a protective atmosphere of argon. $\mathrm{X}$ ray fluorescence analysis revealed that the chemical composition of this alloy was almost the same as the nominal composition. The fully LPSO alloy was homogenized at $350{ }^{\circ} \mathrm{C}$ for 24 hours.

Microstructural characterization of the alloys was carried out by scanning electron microscopy (SEM) and transmission electron microscopy (TEM). Metallographic preparation for optical and SEM observation consisted of mechanical polishing and etching in a solution of $0.5 \mathrm{~g}$ picric acid, $5 \mathrm{ml}$ acetic acid, $20 \mathrm{ml}$ ethanol, $1 \mathrm{ml}$ water and $25 \mathrm{ml}$ methanol. Specimens for TEM observation were prepared by electrolytic polishing using a reactive mixture of $25 \%$ nitric acid and $75 \%$ methanol at $-30{ }^{\circ} \mathrm{C}$ and $20 \mathrm{~V}$. Then, ion milling at liquid nitrogen temperature was used to remove the fine oxide film formed on the surface during electrolytic polishing.

Dilatometry was carried out using a Bähr DIL805A dilatometer. Two samples with a diameter of $5 \mathrm{~mm}$ and a length of $10 \mathrm{~mm}$ were heated by an induction coil. Three heating-cooling cycles between room temperature and $500{ }^{\circ} \mathrm{C}$ were applied using a heating/cooling rate of $5 \mathrm{~K} \mathrm{~min}^{-1}$. The temperature was monitored using a $\mathrm{K}$ thermocouple welded at the centre of the sample. The change in length was measured using an LVDT with an accuracy of $50 \mathrm{~nm}$. The first heating/cooling cycle was disregarded for the calculation of the linear CTE since it may exhibit the effect of relaxation of stresses introduced during production of the material. The measurements where calibrated using a Pt sample subjected to the same heating-cooling cycles as the alloy.

High energy synchrotron radiation diffraction was performed at the P07-HEMS beamline of PETRA III, at the Deutsches Elektronen-Synchrotron (DESY). Cylinders of $10 \mathrm{~mm}$ of length and $5 \mathrm{~mm}$ in diameter were heated using the induction coil of a Bähr DIL805D dilatometer. The measurements were performed under flowing argon. High energy synchrotron radiation diffraction was necessary to acquire simultaneously several reflections of the LSPO phase. The diffraction patterns were recorded using an exposure time of 1 second by a Perkin-Elmer XRD 1622 flatpanel detector with an array of 20482 pixels, with an effective pixel size of $200 \times 200 \mu^{2}$. The beam energy was $100 \mathrm{keV}$ corresponding to a wavelength of $0.0124 \mathrm{~nm}$. $\mathrm{LaB}_{6}$ was used as a reference to calibrate the acquired diffraction spectra. The detectorto-sample distance was $1918.95 \mathrm{~mm}$. Conventional line profiles were obtained by azimuthal integration of the Debye-Scherrer rings using the software Fit2D (Hammersley et al., 1996). Diffraction patterns were obtained at room temperature, $100{ }^{\circ} \mathrm{C}, 200{ }^{\circ} \mathrm{C}$ and $300^{\circ} \mathrm{C}$. The samples were maintained at each temperature 300 seconds before the acquisition of diffraction patterns to homogenize the temperature.

Integrated diffraction patterns were interpreted fitting the whole pattern with the version 4.2 of 
the analysis program TOPAS (Bruker AXS) by using the LeBail's method. In this approach, the superposition of analytical line-profile functions describing each Bragg reflection, and a suitable background model, are fitted to the observed data by a non-linear squares algorithm for the calculation of structural parameters of crystalline phases. In practice, it is necessary to refine simultaneously background functions, peak shapes and lattice parameters. The background was approximated by means of Chevyshev polynomial of 2 nd order and some additional pseudo-Voigt functions to fit the background associated with the direct beam stop and air scattering, Compton scattering and thermal diffuse scattering. The peak shape data were modeled with high accuracy by using the approximation provided by the Thompson-CoxHastings pseudo-Voigt function (Thompson et al., 1987). Finally, the structure used in the refinement was the 18R-type LSPO phase ( $\mathrm{P}_{2} 12$ space group) with the initial cell dimensions reported by Egusa and Abe (2012).

\section{RESULTS AND DISCUSSION}

Figure 1 shows the microstructure of the as-cast $\mathrm{Mg}_{89} \mathrm{Y}_{7} \mathrm{Zn}_{5}$ alloy. It consists mainly of long LPSO laths, which are randomly oriented, with a small volume fraction of the magnesium phase with a dark contrast. This microstructure is in agreement with previous studies of the same alloy (Hagihara et al., 2010b; Garcés et al., 2014a; Garcés et al., 2014b). As the volume fraction of LPSO phase, estimated from 10 images similar to Fig. 1 is $96.8 \pm 0.2 \mathrm{vol} \%$, our polycrystal alloy was quite suitable for the analysis of the thermal expansion coefficient in the $18 \mathrm{R}$ LPSO phase. The microstructure of this alloy was analyzed by TEM to confirm that the LPSO phase consisted of a 18R structure, which it has been indexed by the hexagonal notation by considering



FIgURE 1. Microstructure of the cast $\mathrm{MgY}_{7} \mathrm{Zn}_{5}$ (at.\%) alloy. (White arrows indicate the magnesium islands). a unit cell with a volume three times larger than that of the rhombohedral cell. Figure 2a shows a TEM image of the LPSO phase in the $\mathrm{Mg}_{97} \mathrm{Y}_{7} \mathrm{Zn}_{5}$ alloy at the $\langle 11 \overline{2} 0\rangle_{\alpha}$ zone axis when the $(0002) \mathrm{g}$ is excited. The LPSO crystal structure can be identified through the Selected Area Electron Diffraction pattern (SAED) at the $\langle 11 \overline{2} 0\rangle_{\alpha}$ zone axis or by measuring the fringe spacing in the [0002] direction formed when the g (0002) is excited. The SAED pattern (Fig. 2b) and the fringe spacing of $1.6 \mathrm{~nm}$ confirms the 18R structure.

Figure 3a shows the Debye-Scherrer rings obtained at room temperature. The integration of the DebyeScherrer rings to obtain the diffraction patterns as a function of $2 \theta$ has been carried out using the software Fit2D (Hammersley et al., 1996). Figure 3b shows the indexed $2 \theta$ diffraction patterns for the $\mathrm{Mg}_{89} \mathrm{Y}_{7} \mathrm{Zn}_{5}$ alloy. The crystal structure of the LPSO phase in the cast $\mathrm{Mg}_{89} \mathrm{Y}_{7} \mathrm{Zn}_{5}$ alloy corresponds to the $18 \mathrm{R}$ structure, in agreement with TEM observation, which can be clearly distinguished by the 0003 diffraction peak located at $2 \theta=0.44^{\circ}$. Other diffraction peaks overlap $18 \mathrm{R}$ and $14 \mathrm{H}$ structures. As stated in the introduction section, the LeBail method was used to analyze the XRD pattern of as cast samples considering a $18 \mathrm{R}$ trigonal lattice (space group $\mathrm{P}_{2} 12$ ) as initial structural model. The complexity of this refinement arises from the large primitive unit cell of the material, which results in near 1000 Bragg reflections possible between 0 and $5.6^{\circ}$ when using synchrotron radiation with a wavelength of $0.124 \AA$. A visual examination of Le Bail refinement of a pattern obtained at room temperature indicates a good fit, as shown in Fig. 3c.

Figure 4 shows the relative change in length during the second heating cycle of one of the samples measured by dilatometry. The third cycle shows the same behaviour and it has been omitted to improve legibility. The same is valid for the second and the third cycle of a second sample. The slope of this curve between RT (Room Temperature) and $400{ }^{\circ} \mathrm{C}$ gives the linear CTE



FIgURE 2. a) Bright field TEM image of the LPSO phase in the cast $\mathrm{MgY}_{7} \mathrm{Zn}_{5}($ at. $\%)$ alloy $[\mathrm{B}=\langle 11 \overline{2} 0\rangle$ and $\mathrm{g}=(0002)]$. b) Selected area diffraction pattern of the LPSO phase at the $\langle 11 \overline{2} 0\rangle$ zone axis. 
a)


FIgURE 3. Synchrotron diffraction patterns at room temperature of the cast $\mathrm{MgY}_{7} \mathrm{Zn}_{5}$ (at.\%) alloy: a) obtained from the $2 \mathrm{D}$ detector, $\mathrm{b}$ ) as a function of $2 \theta$ and c) Le Bail refinement of the $2 \theta$ diffraction pattern.

value of the $\mathrm{Mg}_{89} \mathrm{Y}_{7} \mathrm{Zn}_{5}$ alloy in this temperature range. The linear CTE between $\mathrm{RT}$ and $400{ }^{\circ} \mathrm{C}$ obtained as the mean value from the second and third cycle of both samples is $2.7 \times 10^{-5} \mathrm{~K}^{-1}$. This is the linear CTE of the alloy, i.e. it reflects the combined effect of $\sim 97 \mathrm{vol} \%$ of the $18 \mathrm{R}$ LPSO phase and $\sim 3 \operatorname{vol}^{\%} \%$ of $\alpha-\mathrm{Mg}$. In order to separate the CTE value of the LPSO phase, it is necessary to use an alternative method which can evaluate this phase individually. Therefore, the linear CTE of the 18R LPSO phase was estimated considering the evolution of its lattice parameter with 


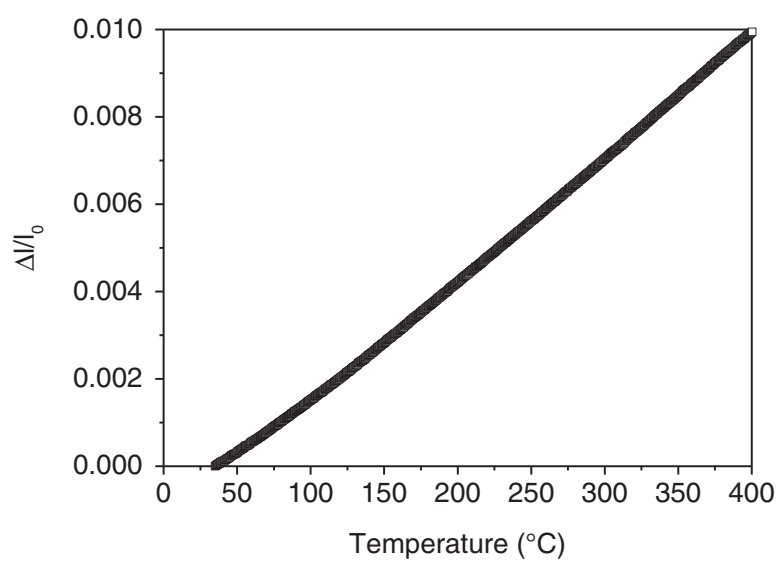

FIGURE 4. Relative change in length of the cast $\mathrm{MgY}_{7} \mathrm{Zn}_{5}\left(\right.$ at.\%) alloy during heating to $400{ }^{\circ} \mathrm{C}$.

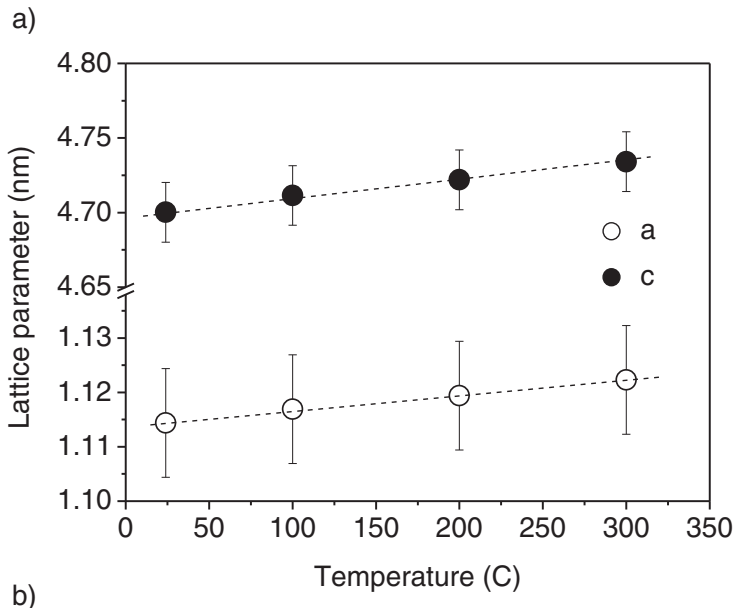

b)

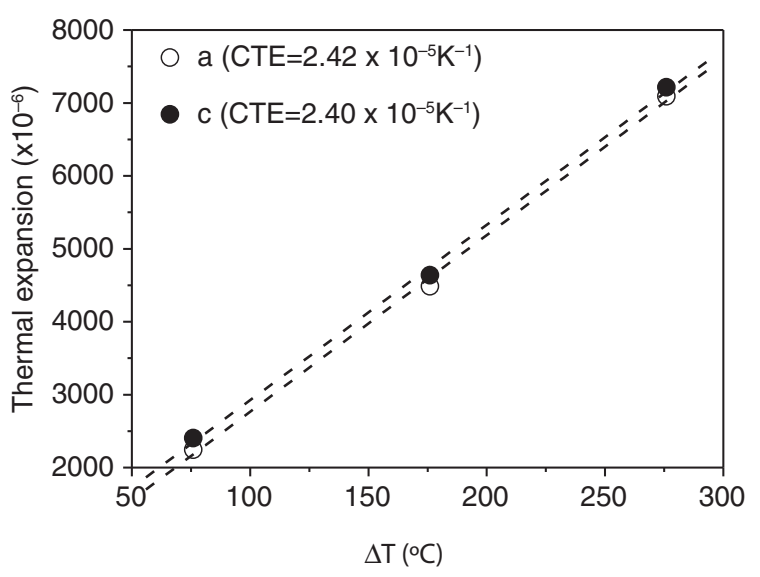

FIGURE 5. a) Evolution of lattice parameters, a and c, of the LPSO phase as a function of temperature. b) Changes of lattice parameters, a and c, of the LPSO phase as function of temperature.

temperature from the diffraction patterns. The evolution of a and $\mathrm{c}$ values with temperature have been calculated fitting the diffraction pattern from
RT to $300{ }^{\circ} \mathrm{C}$ (Fig. 5a). Lattice parameters of the $18 \mathrm{R}$ LPSO phase at room temperature are in agreement with previous references (Garcés et al., 2014a; Garcés et al., 2014b) and increase with temperature as expected. The linear CTE for the lattice parameters, a and c, $\alpha$, can be calculated from (Eq. 1):

$$
\alpha_{\text {lattice }}=\frac{1}{d_{0}}\left(\frac{\Delta d}{\Delta \mathrm{T}}\right)
$$

where $d_{0}$ is the lattice parameter at room temperature. Figure $5 \mathrm{~b}$ shows the thermal elastic expansion $\frac{\Delta d}{d_{0}}$, as a function of the temperature increment. The slope of this curve gives directly the linear CTE for each lattice parameter. CTE values are $2.42 \times 10^{-5}$ and $2.40 \times 10^{-5} \mathrm{~K}^{-1}$ for a and c lattice parameters, respectively. Values are slightly smaller than that obtained by dilatometry as well as the linear CTE of pure magnesium $\left(2.7 \times 10^{-5} \mathrm{~K}^{-1}\right.$ (Smithells, 1992)). Nevertheless, only small thermal mismatch stresses due to differences in CTE will be generated at the $\mathrm{Mg} / \mathrm{LPSO}$ interface. This fact together with the perfect epitaxy between the magnesium and LPSO phases $\left((0001)_{18 R} / /(0001)_{\alpha}\right.$ and $[10 \overline{1} 0]_{18 R} / /[10 \overline{1} 0]_{\alpha}$ (Yamasaki et al., 2011)) explain the good quality of the interface observed during tensile deformation of extruded $\mathrm{MgY}_{2 \mathrm{x}} \mathrm{Zn}_{\mathrm{x}}$ (Yamasaki et al., 2010; Yamasaki et al., 2013) alloys which combine high tensile strength with higher elongation compared with ceramic reinforced composites (Clyne and Withers, 1993) and other magnesium alloys.

\section{CONCLUSIONS}

The linear coefficient of thermal expansion of the 18R LPSO phase has been determined by dilatometry and high energy synchrotron diffraction. It has been demonstrated that the linear CTE of 18R LPSO is very similar to that of magnesium and, therefore, no thermal mismatch stresses are generated at the LPSO-Mg interface during thermal transients.

\section{ACKNOWLEDGEMENTS}

The authors are grateful to MINECO for financial support for this work under project MAT2012-34135. The Deutches ElektronenSynchrotron (DESY) is acknowledged for the provision of beamtime at the P07 beamline of the PETRA III synchrotron radiation facility. Valuable comments from Prof. $\mathrm{M}^{\mathrm{a}}$. Muñoz-Morris and Prof. D. Morris are highly appreciated. We would like to acknowledge the expert support of E. Laurin for assistance with the metallographical preparation. 


\section{REFERENCES}

Arsenault, R.J., Taya, M. (1987). Thermal residual stress in metal matrix composite. Acta Metall. 35, 651-659. http:// dx.doi.org/10.1016/0001-6160(87)90188-X

Clyne, T.W., Withers, P.J. (1993). An introduction to Metal matrix composite, Cambridge University Press, UK

Chen, C.J., Wang, Q.D., Yin, D.D. (2009). Thermal properties of Mg-11Y-5Gd-2Zn-0.5Zr (wt.\%) alloy. J. Alloys Comp. 487 , 560-563. http://dx.doi.org/10.1016/j.jallcom.2009.07.177.

Egusa, D., Abe, E. (2012). The structure of long period stacking/ order Mg-Zn-RE phases with extended non-stoichiometry ranges. Acta Mater. 60, 166-178. http://dx.doi.org/10.1016/j. actamat.2011.09.030.

Garcés, G., Oñorbe, E., Pérez, P., Denks, I.A., Adeva, P. (2009). Evolution of internal strain during plastic deformation in magnesium matrix composites. Mat. Sci. Eng. A 523, 21-26. http://dx.doi.org/10.1016/j.msea.2009.06.026.

Garcés, G., Oñorbe, E., Pérez, P., Klaus, M., Genzel, C., Adeva, P. (2011). Influence of SiC particles on compressive deformation of magnesium matrix composites. Mat. Sci. Eng. A. 533, 119-123. http://dx.doi.org/10.1016/j.msea.2011.10.103.

Garcés, G., Requena, G., Tolnai, D., Pérez, P., Adeva, P., Stark, A. Schell, N. (2014a). Influence of rare-earth addition on the long-period stacking ordered phase in cast $\mathrm{Mg}$ Y-Zn alloys. J. Mater. Sci. 49, 2714-2722. http://dx.doi. org/10.1007/s10853-013-7967-4.

Garcés, G., Muñoz-Morris, M.A., Morris, D.G., Jiménez, J.A., Pérez, P., Adeva, P. (2014b). The role of extrusion texture on strength and its anisotropy in a Mg-base alloy composed of the Long-Period-Structural-Order phase. Intermetallics 55, 167-176. http://dx.doi.org/10.1016/j.intermet.2014.07.015.

Hagihara, K., Kinoshita, A., Sugino, Y., Yamasaki, M., Kawamura, Y., Yasuda, H.Y., Umakoshi, Y. (2010a). Plastic deformation behavior of Mg97Zn1Y2 extruded alloys. T. Nonferr. Metal. Soc. 20, 1259-1268. http://dx.doi. org/10.1016/S1003-6326(09)60288-0.

Hagihara, K., Yokotani, N., Umakoshi, Y. (2010b). Plastic deformation behaviour of $\mathrm{Mg}_{12} \mathrm{YZn}$ with 18R long-period stacking ordered structure. Intermetallics 18, 267-276. http://dx.doi.org/10.1016/j.intermet.2009.07.014

Hammersley, A.P., Svensson, S.O., Hanfland, M., Fitch, A.N., Häusermann, D. (1996). Two-Dimensional Detector
Software: From Real Detector to Idealised Image or TwoTheta Scan. High Pressure Res. 14, 235-248. http://dx.doi. org/10.1080/08957959608201408.

Oñorbe, E., Garcés, G., Pérez, P., Cabeza, S., Klaus, M., Genzel, C., Frutos, E., Adeva, P. (2011). The evolution of internal strain in $\mathrm{Mg}-\mathrm{Y}-\mathrm{Zn}$ alloys with a long period stacking ordered structure. Scr. Mater. 65, 719-722. http://dx.doi. org/10.1016/j.scriptamat.2011.07.017.

Oñorbe, E. Garcés, G., Pérez, P., Adeva, P. (2012). Effect of the LPSO volume fraction on the microstructure and mechanical properties of $\mathrm{Mg}-\mathrm{Y}_{2 \mathrm{x}}-\mathrm{Zn}_{\mathrm{x}}$ alloys. J. Mater. Sci. 47, 1085-1093. http://dx.doi.org/10.1007/s10853-011-5899-4.

Requena, G., Canelo Yubero, D., Corrochano, J., Repper, J., Garcés, G. (2012). Stress relaxation during thermal cycling of particle reinforced aluminium matrix composites. Comp. A 43, 1981-1988. http://dx.doi.org/10.1016/j.compositesa. 2012.07.004.

Smithells (1992). Metals Reference Book Chapter 14-19, Edited by E.A. Brandesnad G.B. Brook Butterworth-Heinemann Ltd Linacre House, Oxford.

Tane, M., Nagai, Y., Kimizuka, H., Hagihara, K., Kawamura, Y. (2014). Elastic properties of an Mg-Zn-Y alloy single crystal with a long-period stacking-ordered structure. Acta Mater. 59, 6338-6351. http://dx.doi.org/10.1016/j. actamat.2013.06.041

Thompson, P., Cox, D.E., Hastings, J.B. (1987). Rietveld refinement of Debye-Scherrer synchrotron X-ray data from $\mathrm{Al}_{2} \mathrm{O}_{3}$. J. Appl. Crystallogr. 20, 79-83. http://dx.doi.org/10.1107/ S0021889887087090.

Yamasaki, M., Hashimoto, K., Hagigara, K., Kawamura, Y. (2010). Multimodal Microstructure Evolution in Wrought Mg-Zn-Y Alloys with High Strength and Increased Ductility. Mater. Sci. Forum 654-656, 615-618.

Yamasaki, M., Hashimoto, K., Hagihara, K., Kawamura, Y. (2011). Effect of multimodal microstructure evolution on mechanical properties of $\mathrm{Mg}-\mathrm{Zn}-\mathrm{Y}$ extruded alloy. Acta Mater. 59, 3646-3658. http://dx.doi.org/10.1016/j. actamat.2011.02.038.

Yamasaki, M., Hagihara, K., Inoue, S., Hardorn, J.P., Kawamura, Y. (2013). Crystallographic classification of kink bands in an extruded $\mathrm{Mg}-\mathrm{Zn}-\mathrm{Y}$ alloy using intragranular misorientation axis analysis. Acta Mater. 61, 2065-2076. http:// dx.doi.org/10.1016/j.actamat.2012.12.026. 